\title{
Unconditional Accounting Conservatism and Real Earnings Management
}

\author{
Han $\mathrm{Li}^{1}$ \\ ${ }^{1}$ SILC Business School, Shanghai University, Shanghai, China \\ Correspondence: Han Li, SILC Business School, Shanghai University, 20 Chengzhong Road, JiaDing District, \\ Shanghai 201800, China. Tel: 86-21-6998-0028, ext.53101.
}

Received: February 25, 2018

Accepted: March 22, 2018

Online Published: April 9, 2018

doi:10.5430/ijfr.v9n2p203

URL: https://doi.org/10.5430/ijfr.v9n2p203

\begin{abstract}
This research examines the relationship between unconditional accounting conservatism and real earnings management in China's corporations. Using the regression models, the real earnings management proxies are found by the abnormal cash flow of operations, the abnormal operation costs and the abnormal discretionary expenses and the aggregated measures. The research sheds light on the negative relationship between unconditional accounting conservatism and real earnings management after controlling internal control quality and audit risk. The results of these inferences remain the same after dealing with the robustness analysis and the endogeneity concerns.
\end{abstract}

Keywords: real earnings management, accounting conservatism, top management team

\section{Introduction}

Earnings management is always the hot debate in accounting research. In accordance with the literature, many factors cause earnings management, for example, internal governance, audit quality, management power and financial debt covenant, etc. With the enact of SOX in USA or similar strict financial reporting regulation in many countires, it is found that the firms' management teams are more likely to manipulate the accounting information by real operating decisions rather than previous accrual-based earnings management. Compared with accrual-based earnings management, real earnings management is much more difficult to be observed by the external and internal control systems. Therefore, more and more researches switch to investigate the inside procedures and the reasons of real earnings management and what are the economic effects for real earnings management. The motivation of this paper is to assess whether accounting conservatism applied in the listed firms can effectively constrain the real earnings management. The history of applying conservatism in accounting can be traced to many years ago. The accounting conservatism is one of the most important principles in accounting framework. Although many previous researches have emphasized on the relationship between conservatism and accrual-based earnings management, very few papers investigate the association between accounting conservatism and real earnings management. This paper tries to fill in this gap.

In this research, the firms that listed in China have been selected as the research samples. Following the research by Roychowdhury (2006) and Cohen et al. (2008), real earnings management (hereafter abbreviated as REM) is measured as the abnormal cash flow of operation, the abnormal production costs, the abnormal discretionary expenses and other aggregated measures. All these abnormal values are the residual values that solved from the regression models. The conservatism principle can be classified into unconditional and conditional ones. In this paper, unconditional conservatism is measured as the non-operating accruals divided by last year's total assets (Givoly and Hayn 2000; Krishnan and Visvanthan, 2008; Zhang and Wang, 2013). The regression results significantly testify that unconditional accounting conservatism is highly associated with the real earnings management. Furthermore, unconditional accounting conservatism is negatively related with real earnings management when controlling the internal control quality and audit risk. Involving with the endogeneity concerns, the business environment index as potential omitted variable is added into the regression model. The inference draws the same results with the original hypotheses. This paper conducts a series of additional tests for the robustness of the results.

This paper sheds light on the relationship between the unconditional accounting conservatism and real earnings management. It contributes to the literature in the following ways. First, very few papers investigate the above relationship. This paper fills in this gap; second, the research in this paper describes a more detail picture about the real earnings management. 
The remainder of this paper is organized as follows. Section II describes the literature review and the hypothesis development. Section III reports the sample selections and measurements about the main variables. Section IV is the research design and the results. Section V reports the endogeneity concerns and the robustness analysis. Section VI conclusions.

\section{Literature Review and Hypothesis Development}

\subsection{Prior Research on Real Earnings Management}

Graham et al. (2005) indicates that CEOs prefer to manipulate earnings to smooth earnings or reach the short-term earnings target which is the quarterly earnings targets or the market analysts' desired targets. The CEOs believe that the outside stakeholders dislike the firms' missing the earnings targets or more volatile of earnings results. The market also would be interested in the earnings results rather than the cash flows of the firms. Therefore, the CEOs would apply the earning management tools to reach the short-term targets. However, these short-term opportunist behaviors would sacrifice the long-term economic value which is to maximize the shareholder's wealth.

There are two kinds of earnings management: accrual earnings management and real earnings management. Accrual based earnings management means the management teams discretionally charge the accrual accounting items and report financial information based on the accounting standards to meet the desired targets which maybe benefit for the specific groups of interests, including not only the shareholders, but also the management teams themselves; Real earnings management indicates the management teams influence the earnings by the real investing, financial and other activities. Real earnings management will impact on cash flows directly and make the future earnings more uncertainty. Therefore, Evans et al. (2015) believes that without constraining earnings by the financial reporting regulation policies, management teams would prefer to the accrual-based earnings management. However, the current change of internal control and information disclosure regulation environment make real earning management more attractive than before for the management teams.

Following the research of earnings management, Roychowdhury (2006) advocates that there is the evidence that the top managers would manipulate the earnings by real earnings management on the purposes of avoiding annual financial reporting losses. Roychwdhury (2006) specially investigates three manipulating channels by the managers to reduce the costs and create the upward profits. Three manipulating methods are (a) sales manipulation (b) discretionary expenses and (c) overproduction. Increasing sales by supplying large percentage of price discounts or lower threshold of credit terms, reducing the discretionary expenditures, for instances, research and development expenditures and decreasing the costs of goods sold by over-production and over-allocating the inventories. These manipulating methods that belong to real earnings management are quite different with the accrual earnings management (Healy and Wahlen 1999; Fields et al.2001). With the enact of the Section 404 of the Sarbans-Oxley Act of 2002 (SOX, 2002) in USA or other supervision regulations in many countires, many accrual earnings management methods are effectively restricted. Therefore, the management teams have the tendency to apply for the real earnings management to meet the requirements of much stricter financial information disclosure and more effective internal control (Järvinen and Myllymäki, 2016)

\subsection{Research on Accounting Conservatism}

The history of application of accounting conservative rules can even be traced to at least 500 years ago. The traditional definition of accounting conservatism can be summarized in the adage "anticipate no profit, but anticipate all losses" (Bliss, 1924). In other words, the verification of good news as profits should be in higher level than the one of bad news as losses (Basu, 1997). The asymmetric treatment of profits and losses leads to undervalue net assets in the current financial reporting periods, although the drawbacks of these treatments cause overvalue net assets in the subsequent year. Agency problem and moral hazard bring the opportunities for the management to introduce bias and noise into financial reporting. Without the constraints on this manipulation behavior, the financial reports cannot neutrally disclose the accounting information under the requirements of accounting regulations and laws. Therefore, accounting conservative treatment would offset the negative effect of managerial short-termism. The accounting conservatism reflects an efficient contracting mechanism that would verify the profits in much higher level than losses, defer the recognition of earnings and understate net assets. The effects of these activities would increase the value for the firm, the shareholders and the other stakeholders of the firm. Moreover, the conservatism would also increase the value by reducing the shareholder's litigation costs. In the litigation periods, the management is motivated to overstate the net assets and therefore increase the expected litigation costs. The constraint of the managements' opportunistic behavior would benefit the shareholders' value of the firm (Watts, 2003).

In the accounting standards, the application of accounting conservatism is commonly applied in dealing with assets, liabilities and income. How to allocate the research and development costs reflects the rules of accounting conservatism. In some courtiers' accounting standards, R\&D should be allocated in short time or even expensed in 
the reporting periods. This treatment will reduce the capitalized assets. Similarly, accelerating the deprecation for the non-current assets will also recognize the specific costs earlier. These activities will understate the net assets in the balance sheet and undervalue the net income in the income statement as well. This kind treatment of accounting conservatism is named as "unconditional conservatism" (Basu, 1997; Givoly et al., 2007).

Another kind of accounting conservatism relates to the timeliness of recognition of the outcomes. For instance, earnings with bad news is recognized much quicker than earnings with good news; the impairments of net assets will be identified at once under the rules of lower of cost or net realizable value, while the corresponding gains or losses will be recognized later; The restriction of dividend payment in debt contract that will avoid the management to maximizing shareholder's value at the cost of sacrificing the interest of debt holders is also the application of accounting conservatism. The second accounting conservatism is called as "conditional conservatism" in the literature (Basu, 1997; Givoly et al., 2007). In this research, unconditional conservatism is used to represent the accounting conservative rules.

\subsection{Hypothese Development}

Current research about the accounting conservatism is summarized as the following subjects: Hsu et al. (2017) find that overconfident CEOs are more likely to defer recognition of bad news. While accounting conservatism can accelerate responding to the bad news. The joint effects of CEOs overconfidence and conservatism are positively related with the firm performance.

The economic effect of accounting conservatism can be reflected by the following research: Donovan et al (2015) believe that more accounting conservatism firms are more likely to have higher asset productivity, less probability of bankruptcy. The creditors of firms with more conservative principles have higher recovery rates. Lee, Li and Sami (2015) also find that the commitment about conditional conservatism of a firm would reduce the audit fess. Moreover, the accounting conservatism can mitigate the negative market reactions to seasoned equity offering (SEOs) announcement (Kim et al., 2013) and improve the internal control quality (Goh and Li, 2011).

After reviewing the literature about the accounting conservatism, very few papers discuss the relationship between accounting conservatism and real earnings management. However, not only accounting conservatism but also real earnings management belongs to essential topics in contemporary accounting research. This paper would make some contribution about this area.

The current regulations and laws about financial reporting are even more strict than before. In U.S.A., the SOX act and its famous section 404 require the listed firms in USA should disclose their effective internal control system. In China, since the new modification of the accounting standards in 2006, Chinese accounting standards have the tendency to harmonize its accounting standards with IAS (international accounting standards). It is found that management teams have less frequent to manipulate the accounting reports by accrual earnings management. However, due to the difficulty of identification about the manipulation in the real operational decisions, for example, overproduction, less expense spending, real earnings management would be the potential alternative for management's accounting manipulation. There are many ways to constraint the real earnings management, for instance, effective internal governance, higher quality of auditing, etc. The accounting conservatism can limit the tendency of the management's manipulation in real operation decisions. In this paper, the accounting conservatism (Conser_NOA) is measured as the unconditional accounting conservatism proxy. Therefore, the hypothesis 1 is as follows:

Hypothesis 1: Unconditional accounting conservatism is highly associated with real earnings management.

$$
\begin{aligned}
\mathrm{REM}_{\mathrm{it}} & =\alpha_{0}+\alpha_{1} \text { Conser_NOA }{ }_{\mathrm{it}}+\alpha_{2} \text { Size }_{\mathrm{it}}++\alpha_{3} \mathrm{ROA}_{\mathrm{it}}+\alpha_{4} \text { Leverage }_{\mathrm{it}}+\alpha_{5} \text { Firm_Age }_{i \mathrm{it}}+\alpha_{6} \text { Industry_FE } \\
& +\alpha_{7} \text { Year_FE }+\varepsilon
\end{aligned}
$$

The internal control is defined by COSO as "a process, effected by an entity's board of directors, management and other personnel, designed to provide reasonable assurance of the achievement of objectives in the effectiveness and efficiency of operations, reliability of financial reporting and compliance with applicable laws and regulations". The COSO framework about the effective internal control system consists of 5 elements: control environment, risk assessment, control activities, information \& communication and monitoring activities. All these components assure higher internal control quality. Furthermore, many researches find that in the firms the better internal control quality has associated with better earnings quality, less cost of financing, less audit fess, better internal governance, etc. If the firms have more effective internal control system, the accounting conservatism would be much effectively applied. Therefore, the hypothesis 2 is as follows:

Hypothesis 2: In accompany with high internal control quality, unconditional accounting conservatism is negatively associated with real earnings management. 


$$
\begin{aligned}
& \mathrm{REM}_{\mathrm{it}}=\alpha_{0}+\alpha_{1} \text { Conser_NOA }{ }_{\mathrm{it}}+\alpha_{2} \mathrm{ICQ}_{\mathrm{it}}+\alpha_{3} \text { Conser_NOA }{ }_{\mathrm{it}} \times \mathrm{ICQ}_{\mathrm{it}}+\alpha_{4} \mathrm{Size}_{\mathrm{it}}++\alpha_{5} \mathrm{ROA}_{\mathrm{it}}+\alpha_{6} \text { Leverage }_{\mathrm{it}}+\alpha_{7} \text { Firm_Age }_{\mathrm{it}} \\
& +\alpha_{8} \text { Industry } \mathrm{FE}+\alpha_{9} \text { Year } \mathrm{Fe}+\varepsilon \quad \text { model (2) }
\end{aligned}
$$

Similar as the internal control quality on the impact of the firms' governance, audit risk also has much influence on the firm's governance. The audit fee can be considered as the proxy for the audit risk. That means higher quality of financial reporting, less audit risk and then less audit fee. If the firms have less audit risk, these firms must also apply the accounting conservatism rules, then less real earning management. The hypothesis 3 is as follows:

Hypothesis 3: In accompany with high audit quality, unconditional accounting conservatism is negatively associated with real earnings management.

$$
\begin{aligned}
& \mathrm{REM}_{\mathrm{it}}=\alpha_{0}+\alpha_{1} \text { Conser_NOA }_{\mathrm{it}}+\alpha_{2} \text { Audit_Fee }_{\mathrm{it}}+\alpha_{3} \text { Conser_NOA }_{\mathrm{it}} \times \text { Audit_Fee }_{\mathrm{it}}+\alpha_{4} \mathrm{Size}_{\mathrm{it}}++\alpha_{5} \mathrm{ROA}_{\mathrm{it}}+\alpha_{6} \text { Leverage }_{\mathrm{it}} \\
& +\alpha_{7} \text { Firm_Age }{ }_{i t}+\alpha_{8} \text { Industry_FE }+\alpha_{9} \text { Year_Fe }+\varepsilon
\end{aligned}
$$

\section{Sample and Measurement About the Main Variable}

\subsection{Data Sources and Sample Selection}

The research in this paper is based on the data of China's stock listed firms. There are 2,162 firms in the selected samples. These samples are selected from 2008 to 2012. To calculate the real earnings management, the previous year data should be included, therefore, the actual selected period is from 2007 to 2012. All the firms' financial accounting information is based on CSMAR database in China. The internal control quality information is from the DIB database. The audit information is also from the CAMAR database. All the data analysis including the descriptive analysis and regression analysis is operated by the STATA 12.1 edition.

\subsection{Dependent Variable}

\section{Real Earnings Management}

With the tendency of increasing the real earnings management by the firms, many researches focus on the measurement of real earnings manipulation. The common methods to measure the real earnings management originated from the research of Roychowdhury (2006) and Cohen et al. (2008). In general, this paper follows the above-mentioned methods. But, due to different features of Chinese listed firms from other countries, some variables are adjusted when I calculate the real earnings management variables. Similar as the research by Roychowdhury (2006) and Cohen et al. (2008), the real earnings management (hereafter abbreviated as REM) proxy can be measured as the REM_CFO, REM_PROD, REM_DISEXP, REM_PROXY. Following the research of Cohen and Zarowin (2010), this paper defines two aggregated measures named as REM1 and REM2.

\section{REM_CFO}

The management teams can supply large amount of trade credits to the customers to enlarge the amounts of sales revenues. The increase of credit sales can be reached by lowering the threshold of credit standards, enlarging the trade credit periods. All these sales promotions can really increase the earnings in the financial reports. However, since the large of amounts of cash flow is locked in the credit sales, credit risk increases and cash flow decreases. This real earnings management would incur the abnormal cash flow (REM_CFO) that is the residual value from model (4).

$$
\frac{C F O_{i, t}}{A_{i, t-1}}=\mathrm{a}_{0}+\frac{\mathrm{a}_{1}}{A_{i, t-1}}+\mathrm{a}_{2} \frac{S A L E S_{i, t}}{A_{i, t-1}}+\mathrm{a}_{3} \frac{\Delta S A L E S_{i, t}}{A_{i, t-1}}+\mu_{i, t}
$$

In the model, $\mathrm{i}$ represents the firm, $\mathrm{t}$ represents the time, CFO means cash flow of operation, $\mathrm{A}$ is the total assets, SALES means the total sales revenues and $\triangle$ SALES means the change of sales revenues between current year and last year. $\mu$ is the residual value that represents the abnormal cash flow of operation due to the real earnings management.

\section{REM_PROD}

The firm's management can also enlarge the production to increase the inventory amount. The fixed costs can be allocated smaller based on the large amount of product units. Furthermore, the increasing amount of closing inventory can reduce the COGS (cost of goods sold), then increase the earnings in the end. The abnormal production costs (REM_PROD) is the residual value from model (5).

$$
\frac{P_{R O D_{i, t}}}{A_{i, t-1}}=\mathrm{a}_{0}+\frac{\mathrm{a}_{1}}{A_{i, t-1}}+\mathrm{a}_{2} \frac{S A L E S_{i, t}}{A_{i, t-1}}+\mathrm{a}_{3} \frac{\Delta S A L E S_{i, t}}{A_{i, t-1}}+\mathrm{a}_{4} \frac{\Delta S A L E S_{i, t-1}}{A_{i, t-1}}+\mu_{i, t}
$$

In the model, $\mathrm{i}$ represent the company, $\mathrm{t}$ also means the time, PROD represents the total production costs, $\mathrm{A}$ represents the total assets. $\mu$ represents the abnormal production costs (REM_PROD) due to real earning management in over production. 


\section{REM DISEXP}

The management can also decrease the discretionary expenses, such as research and development expenses, training expenses and other sales \& administrative expenses. In this way, less expenses make higher earnings in the financial reports. The abnormal discretionary expenses (REM_DISEXP)

$$
\frac{\operatorname{DISEXP}_{i, t}}{A_{i, t-1}}=\mathrm{a}_{0}+\frac{\mathrm{a}_{1}}{A_{i, t-1}}+\mathrm{a}_{2} \frac{\text { SALES }_{i, t-1}}{A_{i, t-1}}+\mu_{i, t}
$$

In this model, DISEXP represents the normal discretionary expenses, $\mu$ is the residual value from the model and represents the abnormal discretionary expenses (REM_DISEXP) due to real earning manipulation.

\section{REM_PROXY}

According to the methods applied by COHEN et al. (2008), if the management is likely to upwards earnings management, the cash flow of operation and discretionary expenses would be less than the normal amount, while, the production costs would be more than the normal amount. Therefore, the residual values REM_CFO and REM_DISEXP from the models (4) and (6) respectively would be negative, the residual value REM_PROD from the model (5) would be positive. Therefore, the composition proxy variable for measuring real earning management is applied as follows:

$$
\text { REM_PROXY=REM_PROD + (- REM_CFO) + (-REM_DISEXP) }
$$

model (7)

\section{REM1}

Because production costs and discretionary expense both belongs to the expenditure, this paper generates an aggregated measures of real earnings management (REM1) to create the total amount of real earnings management. The variable REM1 is defined as follows:

$$
\text { REM1=REM_PROD + REM_DISEXP }
$$

\section{REM2}

If the firm's management team is likely to upwards manipulation earnings, the abnormal cash flow of operation and abnormal discretionary expenses should be negative. The variable REM2 is another aggregated measure for capturing the total amount of the real earnings management. It is defined as follows:

REM2=REM_CFO + REM_DISEXP

\subsection{Testable Variable}

\section{Conservatism}

Accounting conservatism can clearly be classified into two types: unconditional conservatism and conditional conservatism. Unconditional conservatism is continuously downwards (bias) estimation of the net assets and net income in the financial reporting. It is independent on the change of the markets and the firms' operation background; However, conditional conservatism depends on the timeliness of recognition of the outcome. The bad news is recognized quicker than the good news (Beaver and Ryan, 2005). In this paper, accounting conservatism is measured as unconditional conservatism. The variable CONSER_NOA is the proxy for unconditional conservatism (Givoly and Hayn, 2000; Krishnan and Visvanthan, 2008; Zhang and Wang, 2013). In this research, the CONSER_NOA is defined as non-operating accruals divided by the last year's total assets (Notes 1).

$$
\text { CONSER_NOA }{ }_{i t}=-\frac{N O P A C_{i t}}{T A_{i, t-1}}
$$

In this equation, $\mathrm{NOPAC}_{\mathrm{it}}$ is the non-operating accruals. $\mathrm{NOPAC}_{\mathrm{it}}$ is the difference between total non-operating accruals and operating accruals.

The total non-operating accruals $=$ net income + depreciation expenses - cash flow of operation

The operating accruals $=$ the change of accounts receivable + the change of inventory+the change of prepayment the change of accounts payable - the change of tax payable.

$\mathrm{TA}_{\mathrm{i}, \mathrm{t}-1}$ means the last year's total assets.

The negative symbol in this equation fits for the change of conservatism. In other words, the higher of this ratio, the more conservatism would be in the financial reporting.

\section{Internal Control Quality}

An effective internal control system can guarantee the firms' information disclosure and accounting procedures satisfied with the accounting standards and supervision rules. The internal control quality can be assessed by five integrated dimensions: (1) control environment, (2) risk assessment, (3) control activities, (4) information and 
communication, (5) monitoring. The common measurement for the internal control quality in China originates from the databases of the DIB Enterprise Risk Management Technology Co., Ltd. The DIB internal control quality for all the listed firms in China will be disclosed annually.

\section{Audit Risk}

The audit fee reflects the price that the auditing firms charge for the customers. The price would be mainly influenced by the audit risk. Therefore, the audit risk is measured by the audit fee. The higher audit fee charged by the auditing firms means higher audit risk. The less audit fee represents the audited firm less audit risk and higher audit quality.

\subsection{Control Variable}

Firm Size is to measure the firm's assets. Return on assets is to measure the profitability of the firms. Financial leverage represents the debt level based on the total assets. The firm's age is to measure the whole operating time periods since the firms were set up. The control variables also include the fixed effects on industry and years. All the variable definitions are summarized in table 1.

Table 1. Variable definitions

\begin{tabular}{|c|c|c|}
\hline Variable & Description & Definition \\
\hline \multicolumn{3}{|l|}{ Dependent Variable } \\
\hline REM_CFO & Abnormal Cash Flow from REM & $\begin{array}{l}\text { The residual value that actual value minus normal } \\
\text { value in the regression model of cash flow operation }\end{array}$ \\
\hline REM_PROD & $\begin{array}{l}\text { Abnormal Production } \text { Costs } \\
\text { from REM }\end{array}$ & $\begin{array}{l}\text { The residual value that actual value minus normal } \\
\text { value in the regression model of production costs }\end{array}$ \\
\hline$R E M \_D I S E X P$ & $\begin{array}{l}\text { Abnormal Discretionary } \\
\text { Expenses from REM }\end{array}$ & $\begin{array}{l}\text { The residual value that actual value minus normal } \\
\text { value in the regression model of discretionary } \\
\text { expenses }\end{array}$ \\
\hline REM_PROXY & Proxy variable for REM & REM_PROD - REM_CFO - REM_DISEXP \\
\hline REM_l & $\begin{array}{l}\text { No.1 of aggregate measure for } \\
\text { REM }\end{array}$ & the sum of REM_PROD and REM_DISEXP \\
\hline$R E M \_2$ & $\begin{array}{l}\text { No.2 of aggregate measure for } \\
\text { REM }\end{array}$ & the sum of REM_CFO and REM_DISEXP \\
\hline \multicolumn{3}{|l|}{ Testable Variable } \\
\hline CONSER_NOA & $\begin{array}{l}\text { Accounting Conservatism Proxy } \\
\text { Variable }\end{array}$ & $\begin{array}{l}\text { Non-operating accruals of current year divided by } \\
\text { total assets of last year }\end{array}$ \\
\hline$I C Q$ & Internal Control Quality & $\begin{array}{l}\text { Internal Control Quality Index (Source DIB firm } \\
\text { database) }\end{array}$ \\
\hline CONSER_NOA $\times I C Q$ & $\begin{array}{l}\text { Cross item between accounting } \\
\text { conservatism and internal } \\
\text { control quality }\end{array}$ & CONSER_NOA multiplied by ICQ \\
\hline \multicolumn{3}{|l|}{ Control Variable } \\
\hline SIZE & Firm Size & $\begin{array}{l}\text { The natural log of the firm's total assets in year } t \\
\text { (source CSMAR) }\end{array}$ \\
\hline$R O A$ & Return of assets & The net income divided by total assets \\
\hline Leverage & Financial leverage & The total liabilities divided by total assets \\
\hline Firm_Age & Firm Age & $\begin{array}{l}\text { The natural log of the number of years that the firm is } \\
\text { listed in the capital markets (source CSMAR) }\end{array}$ \\
\hline Industry_FE & Fixed effect of industries & $\begin{array}{l}\text { Based on the classification of industry in CSMAR } \\
\text { database }\end{array}$ \\
\hline Year_FE & Fixed effect of years & Years from 2008 to 2012 \\
\hline
\end{tabular}




\section{Research Design and Results}

4.1 Descriptive Data and Correlation Analysis

\subsubsection{Descriptive Analysis}

The results of descriptive analysis are demonstrated in table 2. The results show that the means of all four kinds REM variables (REM_CFO, REM_PROD, REM_DISEXP and REM_PROXY) are positive. That reflects that in Chinese listed firms, real earning management commonly exists. Furthermore, the mean of CONSER_NOA is 0.526, but the median of CONSER_NOA is 0.011. The large deviation between mean and median shows that many listed firms in China apply less conservatism principles. This result also can be reflected by the minimum data of CONSER_NOA (-19.646) and the maximum data of CONSER_NOA (1,591.801).

Table 2. Descriptive analysis

\begin{tabular}{llllllll}
\hline Variable & $\mathrm{N}$ & Mean & P25 & P50 & P75 & Min & Max \\
\hline Main Variable & & & & & & & \\
REM_CFO & 9,870 & 0.010 & -0.075 & 0.013 & 0.081 & -2.951 & 146.257 \\
REM_PROD & 8,931 & 1.540 & 0.369 & 0.604 & 0.943 & -61.130 & $3,259.517$ \\
REM_DISEXP & 9,870 & 0.191 & 0.020 & 0.052 & 0.096 & -0.030 & 471.175 \\
REM_PROXY & 8,931 & 1.324 & 0.281 & 0.543 & 0.924 & -61.263 & $2,642.084$ \\
CONSER_NOA & 9,680 & 0.526 & -0.030 & 0.011 & 0.055 & -19.646 & $1,591.801$ \\
Control Variable & & & & & & & \\
Size & 10,811 & 21.712 & 20.773 & 21.521 & 22.452 & 10.842 & 30.496 \\
ROA & 9,873 & 0.036 & 0.013 & 0.038 & 0.071 & -64.819 & 20.788 \\
Leverage & 10,811 & 0.594 & 0.288 & 0.473 & 0.642 & 0.002 & 142.718 \\
Firm Age & 10,813 & 12.961 & 10.000 & 13.000 & 17.000 & 0.000 & 34.000 \\
\hline
\end{tabular}

\subsubsection{Correlation Analysis}

In table 3, only the dependent variables REM and testable variable CONSER_NOA are included. REM_CFO, REM_PROD, REM_DISEXP and REM_PROXY are all significantly correlated with CONSER_NOA. The probability of the significant is more than $99 \%$. The result is the same with the hypothesis 1 .

Table 3. Correlation matrix with key variables

\begin{tabular}{llllll}
\hline & REM_CFO & REM_PROD & REM_DISEXP & REM_PROXY & CONSER_NOA \\
REM_CFO & 1 & & & & \\
REM_PROD & $0.9912^{*}$ & 1 & & & \\
REM_DISEXP & $0.9878^{*}$ & $0.9892^{*}$ & 1 & 1 & \\
REM_PROXY & $0.9884^{*}$ & $0.9995^{*}$ & $0.9844^{*}$ & 1 & $0.7883^{*}$ \\
CONSER_NOA & $0.7873^{*}$ & $0.7900^{*}$ & $0.7877^{*}$ & 1 \\
\hline
\end{tabular}

Standard errors in parentheses, $* \mathrm{p}<0.01$

To check whether multicollinearity exists or not within all the independent variables, VIF method is applied. The VIF results are shown in table 4. It is obvious that all independent variables' VIF data is less than 10 . This result mean that multicollinearity does not exist among the independent variables.

Table 4. Multicollinearity check by VIF

\begin{tabular}{lll}
\hline Variable & VIF & 1/VIF \\
\hline CONSER_NOA & 1 & 0.9961 \\
Size & 1.06 & 0.9401 \\
ROA & 1.32 & 0.7581 \\
Leverage & 1.36 & 0.7354 \\
Firm_Age & 1.08 & 0.923 \\
\hline
\end{tabular}




\subsection{Multivariate Regression Analysis}

Based on the results of table 5, all the real earnings management (REM) variables are significantly associated with accounting conservatism. The OLS results are demonstrated in 6 columns: REM_CFO, REM_PROD, REM_DISEXP, REM_PROXY, REM1 and REM2. For all results, the probability of significant is more than 99\% $(\mathrm{p}<0.01)$. According to the definition of conservatism proxy (Givoly and Hayn, 2000; Krishnan and Visvanthan, 2008; Zhang and Wang, 2013), the conservatism ratio in column (1) and column (3) should be negative if the firm management teams apply for upwards earnings management. In this paper, the positive conservatism ratio could be explained that the accounting conservatism principles have already constrain the real earnings management. In sum, the hypothsis 1 that unconditional accounting conservatism is highly associated with real earnings management does exist.

Table 5. Regression analysis

\begin{tabular}{|c|c|c|c|c|c|c|}
\hline VARIABLES & $\begin{array}{l}1) \\
\text { REM_CFO }\end{array}$ & $\begin{array}{l}\text { (2) } \\
\text { REM_PROD }\end{array}$ & $\begin{array}{l}\text { (3) } \\
\text { REM_DISEXP }\end{array}$ & $\begin{array}{l}(4) \\
\text { REM_PROXY }\end{array}$ & $\begin{array}{l}5) \\
\text { REM1 } \\
\end{array}$ & $\begin{array}{l}6) \\
\text { REM2 } \\
\end{array}$ \\
\hline CONSER_NOA & $\begin{array}{l}0.0580 * * * \\
(0.000463)\end{array}$ & $\begin{array}{l}1.290 * * * \\
(0.0107)\end{array}$ & $\begin{array}{l}0.188 * * * \\
(0.00148)\end{array}$ & $\begin{array}{l}1.044 * * * \\
(0.00869)\end{array}$ & $\begin{array}{l}1.478 * * * \\
(0.0122)\end{array}$ & $\begin{array}{l}0.246 * * * \\
(0.00194)\end{array}$ \\
\hline Size & $\begin{array}{l}-0.0163 * * \\
(0.00767)\end{array}$ & $\begin{array}{l}0.0816 \\
(0.185)\end{array}$ & $\begin{array}{l}-0.0135 \\
(0.0245)\end{array}$ & $\begin{array}{l}0.111 \\
(0.150)\end{array}$ & $\begin{array}{l}0.0678 \\
(0.211)\end{array}$ & $\begin{array}{l}-0.0298 \\
(0.0321)\end{array}$ \\
\hline ROA & $\begin{array}{l}-0.0524 * * * \\
(0.0158)\end{array}$ & $\begin{array}{l}0.644^{*} \\
(0.376)\end{array}$ & $\begin{array}{l}-0.677 * * * \\
(0.0506)\end{array}$ & $\begin{array}{l}1.338 * * * \\
(0.305)\end{array}$ & $\begin{array}{l}-0.000711 \\
(0.430)\end{array}$ & $\begin{array}{l}-0.729 * * * \\
(0.0662)\end{array}$ \\
\hline Leverage & $\begin{array}{l}0.00143 \\
(0.00426)\end{array}$ & $\begin{array}{l}-0.0310 \\
(0.117)\end{array}$ & $\begin{array}{l}0.0246^{*} \\
(0.0137)\end{array}$ & $\begin{array}{l}-0.0843 \\
(0.0952)\end{array}$ & $\begin{array}{l}0.0192 \\
(0.134)\end{array}$ & $\begin{array}{l}0.0260 \\
(0.0178)\end{array}$ \\
\hline Firm_Age & $\begin{array}{l}0.00220 \\
(0.00222)\end{array}$ & $\begin{array}{l}0.0384 \\
(0.0575)\end{array}$ & $\begin{array}{l}0.00468 \\
(0.00711)\end{array}$ & $\begin{array}{l}0.0319 \\
(0.0467)\end{array}$ & $\begin{array}{l}0.0424 \\
(0.0658)\end{array}$ & $\begin{array}{l}0.00688 \\
(0.00929)\end{array}$ \\
\hline 2.Indcd & $\begin{array}{l}0.0590 \\
(0.163)\end{array}$ & $\begin{array}{l}2.264 \\
(3.770)\end{array}$ & $\begin{array}{l}0.212 \\
(0.520)\end{array}$ & $\begin{array}{l}1.957 \\
(3.061)\end{array}$ & $\begin{array}{l}2.499 \\
(4.314)\end{array}$ & $\begin{array}{l}0.271 \\
(0.680)\end{array}$ \\
\hline 3.Indcd & $\begin{array}{l}-0.0296 \\
(0.163)\end{array}$ & $\begin{array}{l}-1.065 \\
(3.780)\end{array}$ & $\begin{array}{l}-0.270 \\
(0.523)\end{array}$ & $\begin{array}{l}-0.751 \\
(3.069)\end{array}$ & $\begin{array}{l}-1.350 \\
(4.325)\end{array}$ & $\begin{array}{l}-0.300 \\
(0.683)\end{array}$ \\
\hline 4.Indcd & $\begin{array}{l}-0.0486 \\
(0.169)\end{array}$ & $\begin{array}{l}0.154 \\
(3.925)\end{array}$ & $\begin{array}{l}-0.101 \\
(0.541)\end{array}$ & $\begin{array}{l}0.325 \\
(3.187)\end{array}$ & $\begin{array}{l}0.0315 \\
(4.490)\end{array}$ & $\begin{array}{l}-0.149 \\
(0.707)\end{array}$ \\
\hline 5.Indcd & $\begin{array}{l}-0.0918 \\
(0.160)\end{array}$ & $\begin{array}{l}0.389 \\
(3.713)\end{array}$ & $\begin{array}{l}-0.0761 \\
(0.513)\end{array}$ & $\begin{array}{l}0.564 \\
(3.015)\end{array}$ & $\begin{array}{l}0.307 \\
(4.248)\end{array}$ & $\begin{array}{l}-0.168 \\
(0.671)\end{array}$ \\
\hline 6.Inded & $\begin{array}{l}-0.243 \\
(0.164)\end{array}$ & $\begin{array}{l}0.941 \\
(3.793)\end{array}$ & $\begin{array}{l}0.0101 \\
(0.524)\end{array}$ & $\begin{array}{l}1.177 \\
(3.080)\end{array}$ & $\begin{array}{l}0.945 \\
(4.339)\end{array}$ & $\begin{array}{l}-0.233 \\
(0.685)\end{array}$ \\
\hline 2009.Date & $\begin{array}{l}0.000105 \\
(0.0356)\end{array}$ & $\begin{array}{l}-0.184 \\
(0.848)\end{array}$ & $\begin{array}{l}0.00999 \\
(0.114)\end{array}$ & $\begin{array}{l}-0.192 \\
(0.688)\end{array}$ & $\begin{array}{l}-0.176 \\
(0.970)\end{array}$ & $\begin{array}{l}0.0101 \\
(0.149)\end{array}$ \\
\hline 2010.Date & $\begin{array}{l}0.0571 \\
(0.0350)\end{array}$ & $\begin{array}{l}0.373 \\
(0.846)\end{array}$ & $\begin{array}{l}0.115 \\
(0.112)\end{array}$ & $\begin{array}{l}0.195 \\
(0.687)\end{array}$ & $\begin{array}{l}0.493 \\
(0.968)\end{array}$ & $\begin{array}{l}0.172 \\
(0.147)\end{array}$ \\
\hline 2011.Date & $\begin{array}{l}0.0866 * * \\
(0.0337)\end{array}$ & $\begin{array}{l}1.569^{*} \\
(0.834)\end{array}$ & $\begin{array}{l}0.234 * * \\
(0.108)\end{array}$ & $\begin{array}{l}1.215^{*} \\
(0.677)\end{array}$ & $\begin{array}{l}1.833^{*} \\
(0.954)\end{array}$ & $\begin{array}{l}0.320^{* * *} \\
(0.141)\end{array}$ \\
\hline 2012.Date & $\begin{array}{l}0.0532 \\
(0.0332)\end{array}$ & $\begin{array}{l}0.787 \\
(0.805)\end{array}$ & $\begin{array}{l}0.128 \\
(0.106)\end{array}$ & $\begin{array}{l}0.592 \\
(0.654)\end{array}$ & $\begin{array}{l}0.927 \\
(0.921)\end{array}$ & $\begin{array}{l}0.181 \\
(0.139)\end{array}$ \\
\hline Constant & $\begin{array}{l}0.336 \\
(0.227)\end{array}$ & $\begin{array}{l}-2.550 \\
(5.406)\end{array}$ & $\begin{array}{l}0.282 \\
(0.728)\end{array}$ & $\begin{array}{l}-3.155 \\
(4.389)\end{array}$ & $\begin{array}{l}-2.271 \\
(6.185)\end{array}$ & $\begin{array}{l}0.618 \\
(0.952)\end{array}$ \\
\hline Observations & 9,678 & 8,758 & 9,678 & 8,758 & 8,758 & 9,678 \\
\hline Number of ID & 2,431 & 2,194 & 2,431 & 2,194 & 2,194 & 2,431 \\
\hline
\end{tabular}

Standard errors in parentheses, $* * * \mathrm{p}<0.01, * * \mathrm{p}<0.05, * \mathrm{p}<0.1$

When the internal control quality variable is added into the regression model, it is very clear that the CONSER_NOA is significantly with all REM variables $(\mathrm{p}<0.01)$ based on the results in table 6. And the cross item between conservatism and internal control quality are obvious negative associated with REM variables. Its probability of 
significant is more than $99 \%(\mathrm{p}<0.01)$. The hypothesis 2 that unconditional accounting conservatism is negatively associated with real earnings management.

Table 6. Regression analysis

\begin{tabular}{|c|c|c|c|c|c|c|}
\hline & (1) & (2) & (3) & (4) & (5) & (6) \\
\hline VARIABLES & REM_CFO & REM_PROD & REM_DISEXP & REM_PROXY & REM1 & REM2 \\
\hline \multirow{2}{*}{$\begin{array}{l}\text { CONSER_N } \\
\text { OA }\end{array}$} & $0.904 * * *$ & $19.93 * * *$ & $3.011 * * *$ & $16.01 * * *$ & $22.95 * * *$ & $3.915 * * *$ \\
\hline & $(0.00637)$ & $(0.148)$ & $(0.0184)$ & $(0.123)$ & $(0.167)$ & $(0.0245)$ \\
\hline \multirow[t]{2}{*}{ ICQ } & $-0.000328 * * *$ & $-0.00477 * * *$ & $-0.000537 * * *$ & $-0.00387 * * *$ & $-0.00532 * * *$ & $-0.000865^{* * * *}$ \\
\hline & $(6.56 e-05)$ & $(0.00156)$ & $(0.000190)$ & (0.00130) & $(0.00176)$ & $(0.000253)$ \\
\hline \multirow{2}{*}{$\begin{array}{l}\text { CONSER_N } \\
\text { OA×ICQ }\end{array}$} & $-0.00146 * * *$ & $-0.0321 * * *$ & $-0.00486^{* * *}$ & $-0.0258 * * *$ & $-0.0369 * * *$ & $-0.00631 * * *$ \\
\hline & $(1.09 \mathrm{e}-05)$ & $(0.000255)$ & $(3.17 \mathrm{e}-05)$ & $(0.000211)$ & $(0.000288)$ & $(4.22 \mathrm{e}-05)$ \\
\hline \multirow[t]{2}{*}{ Size } & $0.0156^{* * *}$ & $0.689 * * *$ & $0.0746^{* * *}$ & $0.595 * * *$ & $0.765^{* * *}$ & $0.0902 * * *$ \\
\hline & $(0.00584)$ & $(0.142)$ & (0.0169) & $(0.118)$ & $(0.161)$ & $(0.0225)$ \\
\hline \multirow[t]{2}{*}{ ROA } & $0.994 * * *$ & $24.03 * * *$ & $2.687 * * *$ & $20.36 * * *$ & $26.72 * * *$ & $3.681 * * *$ \\
\hline & $(0.0137)$ & $(0.323)$ & $(0.0397)$ & $(0.268)$ & $(0.365)$ & $(0.0528)$ \\
\hline \multirow[t]{2}{*}{ Leverage } & $-0.00884 * * *$ & $-0.319 * * *$ & $-0.0155^{*}$ & $-0.284 * * *$ & $-0.340 * * *$ & $-0.0244 * *$ \\
\hline & $(0.00302)$ & $(0.0777)$ & $(0.00872)$ & $(0.0644)$ & $(0.0877)$ & $(0.0116)$ \\
\hline \multirow[t]{2}{*}{ Firm_Age } & $0.00293 * *$ & $0.0694 *$ & $0.00911 * *$ & $0.0563 *$ & $0.0788 *$ & $0.0120 * *$ \\
\hline & $(0.00143)$ & $(0.0366)$ & $(0.00414)$ & $(0.0304)$ & $(0.0413)$ & $(0.00552)$ \\
\hline \multirow[t]{2}{*}{ 2.Indcd } & $-0.193^{*}$ & -3.743 & $-0.705^{* *}$ & -2.855 & $-4.442 *$ & $-0.899 * *$ \\
\hline & $(0.101)$ & (2.344) & $(0.291)$ & (1.945) & $(2.645)$ & $(0.388)$ \\
\hline \multirow[t]{2}{*}{ 3.Indcd } & -0.134 & -3.291 & $-0.650 * *$ & -2.519 & -3.932 & $-0.784 * *$ \\
\hline & $(0.101)$ & $(2.352)$ & $(0.292)$ & (1.951) & (2.654) & $(0.389)$ \\
\hline \multirow[t]{2}{*}{ 4.Indcd } & $-0.215^{* *}$ & -3.547 & $-0.689 * *$ & -2.651 & -4.233 & $-0.904 * *$ \\
\hline & $(0.105)$ & $(2.441)$ & $(0.302)$ & (2.025) & (2.754) & $(0.403)$ \\
\hline \multirow[t]{2}{*}{ 5.Inded } & $-0.249 * *$ & -3.258 & $-0.662 * *$ & -2.349 & -3.915 & $-0.911 * *$ \\
\hline & $(0.0991)$ & (2.307) & $(0.287)$ & (1.914) & (2.603) & $(0.382)$ \\
\hline \multirow[t]{2}{*}{ 6.Inded } & $-0.398 * * *$ & -2.836 & $-0.591 * *$ & -1.850 & -3.427 & $-0.988 * *$ \\
\hline & $(0.101)$ & (2.358) & $(0.293)$ & (1.956) & (2.660) & $(0.390)$ \\
\hline \multirow[t]{2}{*}{ 2009.Date } & -0.0105 & -0.469 & -0.0360 & -0.415 & -0.512 & -0.0465 \\
\hline & $(0.0223)$ & $(0.532)$ & $(0.0645)$ & $(0.441)$ & $(0.600)$ & (0.0859) \\
\hline \multirow[t]{2}{*}{ 2010.Date } & 0.00109 & $-1.024^{*}$ & -0.0811 & $-0.929 * *$ & $-1.114^{*}$ & -0.0800 \\
\hline & $(0.0221)$ & $(0.530)$ & $(0.0639)$ & $(0.440)$ & $(0.598)$ & $(0.0851)$ \\
\hline \multirow[t]{2}{*}{ 2011.Date } & 0.0242 & -0.0835 & -0.00253 & -0.0933 & -0.0862 & 0.0217 \\
\hline & $(0.0217)$ & $(0.537)$ & $(0.0628)$ & $(0.445)$ & (0.606) & $(0.0837)$ \\
\hline \multirow[t]{2}{*}{ 2012.Date } & 0.0188 & -0.154 & -0.00364 & -0.160 & -0.161 & 0.0152 \\
\hline & (0.0209) & $(0.507)$ & $(0.0605)$ & $(0.421)$ & $(0.573)$ & $(0.0806)$ \\
\hline \multirow[t]{2}{*}{ Constant } & 0.0235 & $-8.930 * *$ & $-0.694 *$ & $-8.193 * * *$ & $-9.640 * *$ & -0.671 \\
\hline & $(0.145)$ & $(3.477)$ & $(0.421)$ & $(2.884)$ & (3.924) & $(0.560)$ \\
\hline Observations & 8,714 & 7,968 & 8,714 & 7,968 & 7,968 & 8,714 \\
\hline Number of & 2,297 & 2,084 & 2,297 & 2,084 & 2,084 & 2,297 \\
\hline
\end{tabular}

Standard errors in parentheses, $* * * \mathrm{p}<0.01, * * \mathrm{p}<0.05, * \mathrm{p}<0.1$ 
According to the information in table 7, the accounting conservatism is highly related with all REM variables $(\mathrm{p}<0.01)$ when the audit risk that measured by the audit fee is considered in the regression model. It means that with higher strict audit control and regulation, the accounting conservatism of the management teams can really matter for the real earnings management. Higher accounting conservatism is associated with lower probability of real earning management. Therefore, the hypothesis 3 that unconditional accounting conservatism is negatively associated with real earnings management does exist.

Table 7. Regression analysis

\begin{tabular}{|c|c|c|c|c|c|c|}
\hline VARIABLES & $\begin{array}{l}\text { (1) } \\
\text { REM_CFO }\end{array}$ & $\begin{array}{l}(2) \\
\text { REM_PROD }\end{array}$ & $\begin{array}{l}(3) \\
\text { REM_DISEXP }\end{array}$ & $\begin{array}{l}\text { (4) } \\
\text { REM_PROXY }\end{array}$ & $\begin{array}{l}(5) \\
\text { REM1 } \\
\end{array}$ & $\begin{array}{l}(6) \\
\text { REM2 } \\
\end{array}$ \\
\hline CONSER_NOA & $\begin{array}{l}-1.473 * * * \\
(0.0155)\end{array}$ & $\begin{array}{l}-33.10 * * * \\
(0.350)\end{array}$ & $\begin{array}{l}-4.725 * * * \\
(0.0495)\end{array}$ & $\begin{array}{l}-26.90 * * * \\
(0.284)\end{array}$ & $\begin{array}{l}-37.83 * * * \\
(0.401)\end{array}$ & $\begin{array}{l}-6.198 * * * \\
(0.0645)\end{array}$ \\
\hline $\begin{array}{l}\text { CONSER_NOA } \\
\times \text { Audit_Fee }\end{array}$ & $\begin{array}{l}0.116 * * * \\
(0.00118)\end{array}$ & $\begin{array}{l}2.617 * * * \\
(0.0266)\end{array}$ & $\begin{array}{l}0.374 * * * \\
(0.00376)\end{array}$ & $\begin{array}{l}2.127 * * * \\
(0.0216)\end{array}$ & $\begin{array}{l}2.991 * * * \\
(0.0305)\end{array}$ & $\begin{array}{l}0.490 * * * \\
(0.00491)\end{array}$ \\
\hline LnAudit_Fee & $\begin{array}{l}-0.0295^{*} \\
(0.0161)\end{array}$ & $\begin{array}{l}0.0291 \\
(0.382)\end{array}$ & $\begin{array}{l}0.0621 \\
(0.0516)\end{array}$ & $\begin{array}{l}0.00673 \\
(0.309)\end{array}$ & $\begin{array}{l}0.0848 \\
(0.437)\end{array}$ & $\begin{array}{l}0.0326 \\
(0.0672)\end{array}$ \\
\hline Size & $\begin{array}{l}-0.00565 \\
(0.00887)\end{array}$ & $\begin{array}{l}0.0297 \\
(0.207)\end{array}$ & $\begin{array}{l}-0.0421 \\
(0.0283)\end{array}$ & $\begin{array}{l}0.0735 \\
(0.168)\end{array}$ & $\begin{array}{l}-0.00982 \\
(0.237)\end{array}$ & $\begin{array}{l}-0.0477 \\
(0.0369)\end{array}$ \\
\hline ROA & $\begin{array}{l}-0.112 * * * \\
(0.0124)\end{array}$ & $\begin{array}{l}-0.494^{*} \\
(0.286)\end{array}$ & $\begin{array}{l}-0.924 * * * \\
(0.0396)\end{array}$ & $\begin{array}{l}0.515^{* *} \\
(0.232)\end{array}$ & $\begin{array}{l}-1.395^{* * * *} \\
(0.327)\end{array}$ & $\begin{array}{l}-1.037 * * * \\
(0.0516)\end{array}$ \\
\hline Leverage & $\begin{array}{l}0.00382 \\
(0.00356)\end{array}$ & $\begin{array}{l}0.0123 \\
(0.0888)\end{array}$ & $\begin{array}{l}0.0289 * * \\
(0.0114)\end{array}$ & $\begin{array}{l}-0.0389 \\
(0.0720)\end{array}$ & $\begin{array}{l}0.0577 \\
(0.102)\end{array}$ & $\begin{array}{l}0.0327 * * \\
(0.0148)\end{array}$ \\
\hline Firm_Age & $\begin{array}{l}0.00284 * \\
(0.00173)\end{array}$ & $\begin{array}{l}0.0590 \\
(0.0432)\end{array}$ & $\begin{array}{l}0.00642 \\
(0.00552)\end{array}$ & $\begin{array}{l}0.0487 \\
(0.0350)\end{array}$ & $\begin{array}{l}0.0657 \\
(0.0495)\end{array}$ & $\begin{array}{l}0.00926 \\
(0.00719)\end{array}$ \\
\hline 2.Indcd & $\begin{array}{l}0.0289 \\
(0.121)\end{array}$ & $\begin{array}{l}1.898 \\
(2.741)\end{array}$ & $\begin{array}{l}0.164 \\
(0.386)\end{array}$ & $\begin{array}{l}1.680 \\
(2.223)\end{array}$ & $\begin{array}{l}2.077 \\
(3.140)\end{array}$ & $\begin{array}{l}0.193 \\
(0.504)\end{array}$ \\
\hline 3.Indcd & $\begin{array}{l}-0.0819 \\
(0.122)\end{array}$ & $\begin{array}{l}-1.751 \\
(2.754)\end{array}$ & $\begin{array}{l}-0.373 \\
(0.389)\end{array}$ & $\begin{array}{l}-1.281 \\
(2.233)\end{array}$ & $\begin{array}{l}-2.139 \\
(3.155)\end{array}$ & $\begin{array}{l}-0.455 \\
(0.507)\end{array}$ \\
\hline 4.Indcd & $\begin{array}{l}-0.0469 \\
(0.126)\end{array}$ & $\begin{array}{l}0.530 \\
(2.851)\end{array}$ & $\begin{array}{l}-0.0470 \\
(0.401)\end{array}$ & $\begin{array}{l}0.637 \\
(2.312)\end{array}$ & $\begin{array}{l}0.467 \\
(3.266)\end{array}$ & $\begin{array}{l}-0.0939 \\
(0.523)\end{array}$ \\
\hline 5.Indcd & $\begin{array}{l}-0.0882 \\
(0.119)\end{array}$ & $\begin{array}{l}0.978 \\
(2.698)\end{array}$ & $\begin{array}{l}0.00128 \\
(0.381)\end{array}$ & $\begin{array}{l}1.066 \\
(2.188)\end{array}$ & $\begin{array}{l}0.979 \\
(3.091)\end{array}$ & $\begin{array}{l}-0.0869 \\
(0.497)\end{array}$ \\
\hline 6.Indcd & $\begin{array}{l}-0.247 * * \\
(0.122)\end{array}$ & $\begin{array}{l}1.175 \\
(2.761)\end{array}$ & $\begin{array}{l}0.0385 \\
(0.390)\end{array}$ & $\begin{array}{l}1.385 \\
(2.239)\end{array}$ & $\begin{array}{l}1.210 \\
(3.163)\end{array}$ & $\begin{array}{l}-0.208 \\
(0.508)\end{array}$ \\
\hline 2009.Date & $\begin{array}{l}-0.0446 \\
(0.0282)\end{array}$ & $\begin{array}{l}-1.196^{*} \\
(0.656)\end{array}$ & $\begin{array}{l}-0.131 \\
(0.0900)\end{array}$ & $\begin{array}{l}-1.009 * \\
(0.532)\end{array}$ & $\begin{array}{l}-1.336^{*} \\
(0.751)\end{array}$ & $\begin{array}{l}-0.175 \\
(0.117)\end{array}$ \\
\hline 2010.Date & $\begin{array}{l}0.0188 \\
(0.0277)\end{array}$ & $\begin{array}{l}-0.474 \\
(0.652)\end{array}$ & $\begin{array}{l}0.00490 \\
(0.0886)\end{array}$ & $\begin{array}{l}-0.492 \\
(0.529)\end{array}$ & $\begin{array}{l}-0.473 \\
(0.747)\end{array}$ & $\begin{array}{l}0.0238 \\
(0.115)\end{array}$ \\
\hline 2011.Date & $\begin{array}{l}0.0212 \\
(0.0268)\end{array}$ & $\begin{array}{l}-0.00696 \\
(0.643)\end{array}$ & $\begin{array}{l}0.0261 \\
(0.0857)\end{array}$ & $\begin{array}{l}-0.0524 \\
(0.521)\end{array}$ & $\begin{array}{l}0.0229 \\
(0.736)\end{array}$ & $\begin{array}{l}0.0473 \\
(0.112)\end{array}$ \\
\hline 2012.Date & $\begin{array}{l}0.0163 \\
(0.0259)\end{array}$ & $\begin{array}{l}-0.169 \\
(0.615)\end{array}$ & $\begin{array}{l}-0.0107 \\
(0.0829)\end{array}$ & $\begin{array}{l}-0.175 \\
(0.499)\end{array}$ & $\begin{array}{l}-0.177 \\
(0.705)\end{array}$ & $\begin{array}{l}0.00558 \\
(0.108)\end{array}$ \\
\hline Constant & $\begin{array}{l}0.536 * * * \\
(0.191)\end{array}$ & $\begin{array}{l}-1.511 \\
(4.464)\end{array}$ & $\begin{array}{l}0.136 \\
(0.609)\end{array}$ & $\begin{array}{l}-2.211 \\
(3.620)\end{array}$ & $\begin{array}{l}-1.354 \\
(5.113)\end{array}$ & $\begin{array}{l}0.673 \\
(0.794)\end{array}$ \\
\hline $\begin{array}{l}\text { Observations } \\
\text { Number of ID }\end{array}$ & $\begin{array}{l}8,481 \\
2,334\end{array}$ & $\begin{array}{l}7,744 \\
2,100\end{array}$ & $\begin{array}{l}8,481 \\
2,334\end{array}$ & $\begin{array}{l}7,744 \\
2,100\end{array}$ & $\begin{array}{l}7,744 \\
2,100\end{array}$ & $\begin{array}{l}8,481 \\
2,334\end{array}$ \\
\hline
\end{tabular}

Standard errors in parentheses, $* * * \mathrm{p}<0.01, * * \mathrm{p}<0.05, * \mathrm{p}<0.1$

\section{Endogeneity Concerns and Robustness Analysis}

These research results are subject to endogeneity problems because the accounting conservatism would be endogenously determined. The factors that influencing the accounting conservatism would also take an impact on 
real earnings management. For example, some social values and norms, i.e. higher risk uncertain culture, can influence the application of accounting conservatism and real earnings management. Another example, the levels of market development in the regions where the listed firms located might also affect conservatism and real earnings management. But these arguments cannot explain the research results in this paper.

To solve for the endogeneity problems, the possible omitted variable, such as business environment index that represents the market development in provinces in China, is added into the regression model (3). The business environment index (BEI) in China is adapted from the research of Wang et al. (2013). The regression results are showed in table 8 . The results in this paper still have been strongly supported.

Table 8. Endogeneity check

\begin{tabular}{|c|c|c|c|c|}
\hline VARIABLES & $\begin{array}{l}(1) \\
\text { REM_CFO }\end{array}$ & $\begin{array}{l}\text { (2) } \\
\text { REM_PROD }\end{array}$ & $\begin{array}{l}(3) \\
\text { REM_DISEXP }\end{array}$ & $\begin{array}{l}\text { (4) } \\
\text { REM_PROXY }\end{array}$ \\
\hline CONSER_NOA & $\begin{array}{l}-3.483 * * * \\
(0.0229)\end{array}$ & $\begin{array}{l}-77.86 * * * \\
(0.509)\end{array}$ & $\begin{array}{l}-11.06 * * * \\
(0.0761)\end{array}$ & $\begin{array}{l}-63.31 * * * \\
(0.410)\end{array}$ \\
\hline LnAudit_Fee & $\begin{array}{l}-0.0156 \\
(0.0159)\end{array}$ & $\begin{array}{l}0.147 \\
(0.362)\end{array}$ & $\begin{array}{l}0.0837 * \\
(0.0499)\end{array}$ & $\begin{array}{l}0.0803 \\
(0.293)\end{array}$ \\
\hline $\begin{array}{l}\text { CONSER_NOA } \\
\times \text { Audit Fee }\end{array}$ & $\begin{array}{l}0.268 * * * \\
(0.00173)\end{array}$ & $\begin{array}{l}5.982 * * * \\
(0.0384)\end{array}$ & $\begin{array}{l}0.850 * * * \\
(0.00574)\end{array}$ & $\begin{array}{l}4.864 * * * \\
(0.0309)\end{array}$ \\
\hline Size & $\begin{array}{l}-0.0158^{*} \\
(0.00871)\end{array}$ & $\begin{array}{l}-0.0938 \\
(0.197)\end{array}$ & $\begin{array}{l}-0.0662 * * \\
(0.0271)\end{array}$ & $\begin{array}{l}-0.0106 \\
(0.159)\end{array}$ \\
\hline ROA & $\begin{array}{l}-0.169 * * * \\
(0.0124)\end{array}$ & $\begin{array}{l}-2.238 * * * \\
(0.276)\end{array}$ & $\begin{array}{l}-1.005 * * * \\
(0.0408)\end{array}$ & $\begin{array}{l}-1.088 * * * \\
(0.223)\end{array}$ \\
\hline Leverage & $\begin{array}{l}0.0115 * * \\
(0.00518)\end{array}$ & $\begin{array}{l}0.0179 \\
(0.115)\end{array}$ & $\begin{array}{l}0.0850 * * * \\
(0.0168)\end{array}$ & $\begin{array}{l}-0.0802 \\
(0.0928)\end{array}$ \\
\hline Firm_Age & $\begin{array}{l}0.000950 \\
(0.00170)\end{array}$ & $\begin{array}{l}0.0388 \\
(0.0408)\end{array}$ & $\begin{array}{l}0.00190 \\
(0.00522)\end{array}$ & $\begin{array}{l}0.0343 \\
(0.0331)\end{array}$ \\
\hline BEI & $\begin{array}{l}-0.168 * * * \\
(0.0620)\end{array}$ & $\begin{array}{l}-1.699 \\
(1.410)\end{array}$ & $\begin{array}{l}-0.231 \\
(0.189)\end{array}$ & $\begin{array}{l}-1.274 \\
(1.144)\end{array}$ \\
\hline 2.Indcd & $\begin{array}{l}0.0232 \\
(0.135)\end{array}$ & $\begin{array}{l}1.815 \\
(2.940)\end{array}$ & $\begin{array}{l}0.114 \\
(0.409)\end{array}$ & $\begin{array}{l}1.642 \\
(2.386)\end{array}$ \\
\hline 3.Indcd & $\begin{array}{l}-0.0794 \\
(0.136)\end{array}$ & $\begin{array}{l}-1.806 \\
(2.957)\end{array}$ & $\begin{array}{l}-0.418 \\
(0.412)\end{array}$ & $\begin{array}{l}-1.303 \\
(2.399)\end{array}$ \\
\hline 4.Inded & $\begin{array}{l}-0.0449 \\
(0.139)\end{array}$ & $\begin{array}{l}0.864 \\
(3.050)\end{array}$ & $\begin{array}{l}-0.0727 \\
(0.424)\end{array}$ & $\begin{array}{l}0.978 \\
(2.475)\end{array}$ \\
\hline 5.Indcd & $\begin{array}{l}-0.0834 \\
(0.133)\end{array}$ & $\begin{array}{l}1.040 \\
(2.902)\end{array}$ & $\begin{array}{l}-0.0347 \\
(0.404)\end{array}$ & $\begin{array}{l}1.153 \\
(2.354)\end{array}$ \\
\hline 6.Indcd & $\begin{array}{l}-0.235^{*} \\
(0.136)\end{array}$ & $\begin{array}{l}1.516 \\
(2.964)\end{array}$ & $\begin{array}{l}0.0374 \\
(0.413)\end{array}$ & $\begin{array}{l}1.704 \\
(2.405)\end{array}$ \\
\hline 2010.Date & $\begin{array}{l}0.0454 * * * \\
(0.0170)\end{array}$ & $\begin{array}{l}0.287 \\
(0.390)\end{array}$ & $\begin{array}{l}0.0785 \\
(0.0579)\end{array}$ & $\begin{array}{l}0.163 \\
(0.314)\end{array}$ \\
\hline 2011.Date & $\begin{array}{l}0.0207 \\
(0.0167)\end{array}$ & $\begin{array}{l}0.120 \\
(0.389)\end{array}$ & $\begin{array}{l}0.0212 \\
(0.0566)\end{array}$ & $\begin{array}{l}0.0886 \\
(0.313)\end{array}$ \\
\hline 2012.Date & $\begin{array}{l}0.0381 * * \\
(0.0166)\end{array}$ & $\begin{array}{l}0.542 \\
(0.382)\end{array}$ & $\begin{array}{l}0.0629 \\
(0.0557)\end{array}$ & $\begin{array}{l}0.437 \\
(0.308)\end{array}$ \\
\hline Constant & $\begin{array}{l}1.082 * * * \\
(0.267)\end{array}$ & $\begin{array}{l}4.325 \\
(5.977)\end{array}$ & $\begin{array}{l}1.073 \\
(0.812)\end{array}$ & $\begin{array}{l}2.072 \\
(4.848)\end{array}$ \\
\hline Observations & 7,159 & 6,528 & 7,159 & 6,528 \\
\hline
\end{tabular}

Standard errors in parentheses, $* * * \mathrm{p}<0.01, * * \mathrm{p}<0.05, * \mathrm{p}<0.1$ 
Regards to the robustness analysis, some alternative variables for measuring accounting conservatism have been applied in the regression models. For example, the CONSER_NOA has been calculated again by dividing the average 3 years assets rather than last year's assets in current method. The inference would also keep same with the original hypotheses.

\section{Summary}

\subsection{Conclusions}

This paper sheds light on the association between unconditional accounting conservatism and real earnings management. With the tendency of stricter financial regulation and control, it is observed that the firms' management teams have less motivation to manipulate the financial reports by accrual-based earnings management. However, real earnings management would become an alternative for the management teams on the purposes of benefiting their own interests rather than maximizing the shareholder's wealth. This paper measures the real earnings management in different ways. These methods mainly involve in calculating the abnormal cash flow of operations, the abnormal production costs, the abnormal discretionary expenses and the aggregate measures. On the other side, the method for solving the testable variable conservatism is followed by Givoly and Hayn (2000). The unconditional conservatism is the result of non-accrual operation divided by last year's total assets. This paper finds that unconditional accounting conservatism is highly associated with real earnings management. Moreover, the accounting unconditional conservatism is negatively related with real earnings management after controlling the internal control quality and audit risks. These results are robust to alternative measures of accounting conservatism to influence the real earnings management. The inference keeps the same after dealing with the endogeneity concerns. This research extends the knowledge of earnings management. It would benefit for the academic researches and practical activities.

\subsection{Limitations and Further Research Suggestions}

In this research, real earnings management has not been classified into upwards earnings manipulation and downwards earnings manipulation. However, the purposes of earnings management are quite complex. Some firms are more likely to overvalue the earnings for good performance, while, some firms are to undervalue the earnings for the tax purposes. Therefore, further research can investigate the difference features between these different direction earnings management.

\section{References}

Basu, S. (1997). The conservatism principle and the asymmetric timeliness of earnings. Journal of Accounting and Economics, 24(1), 3-37. https://doi.org/10.1016/S0165-4101(97)00014-1

Beaver, W. H., \& Ryan, S. G. (2005). Conditional and unconditional conservatism: concepts and modeling. Review of Accounting Studies, 10(2-3), 269-309. https://doi.org/10.1007/s11142-005-1532-6

Bliss, J. H. (1924). Management through Accounts. New York, NY: The Ronald Press Co.

Cheng, Q., \& Lee, J. (2016). Internal Governance and Real Earnings Management. The Accounting Review, 91, 1051-1085. https://doi.org/10.2308/accr-51275

Cohen, D. A., Dey, A., \& Lys, T. Z. (2008). Real and accrual-based earnings management in the pre-and $\begin{array}{lllll}\text { post-Sarbanes-Oxley periods. The Accounting Review, } & \text { 757-787. }\end{array}$ https://doi.org/10.2308/accr.2008.83.3.757

Cohen, D. A., \& Zarowin, P. (2010). Accrual-based and real earnings management activities around seasoned equity offerings. Journal of Accounting and Economics, 50, 2-19. https://doi.org/10.1016/j.jacceco.2010.01.002

Donovan, J., Frankel, R. M., \& Martin, X. (2015). Accounting conservatism and creditor recovery rate. The Accounting Review, 90(6), 2267-2303. https://doi.org/10.2308/accr-51045

Evans, M. E., Houston, R. W., Peters, M. F., \& Pratt, J. H. (2015). Reporting regulatory environments and earnings management: U.S. and Non-U.S. firms using U.S. GAAP or IFRS. The Accounting Review, 90(5), 1969-1994. https://doi.org/10.2308/accr-51008

Givoly, D., \& Hayn, C. (2000). The changing time-series properties of earnings, cash flows and accruals: has financial reporting become more conservative? Journal of Accounting and Economics, 29(3), 287-320. https://doi.org/10.1016/S0165-4101(00)00024-0

Givoly, D., Hayn, C. K., \& Natarajan, A. (2007). Measuring reporting conservatism. The Accounting Review, 82(1), 65-106. https://doi.org/10.2308/accr.2007.82.1.65 
Goh, B. W., \& Li, D. (2011). Internal controls and conditional conservatism. The Accounting Review, 86(3), 975-1005. https://doi.org/10.2308/accr.00000041

Graham, J., Harvey, C., \& Rajgopal, S. (2005). The economic implications of corporate financial reporting. Journal of Accounting and Economics, 40(1-3), 3-73. https://doi.org/10.1016/j.jacceco.2005.01.002

Healy, P. M., \& Wahlen, J. (1999). A review of the earnings management literature and its implications for standard setting. Accounting Horizons, 13(4), 365-383. https://doi.org/10.2308/acch.1999.13.4.365

Hsu, C., Novoselor, K. E., \& Wang, R. C. (2017). Does accounting conservatism mitigate the shortcomings of CEO overconfidence? The Accounting Review, 92(6), 77-101. https://doi.org/10.2308/accr-51718

Järvinen, T., \& Myllymäki, E. R. (2016). Real earnings management before and after reporting SOX 404 material weaknesses. Accounting Horizons, 30(1), 119-141. https://doi.org/10.2308/acch-51310

Kim, Y., Li, S., Pan, C., \& Zuo, L. (2013). The role of accounting conservatism in the equity market: evidence from seasoned equity offerings. The Accounting Review, 88(4), 1327-1356. https://doi.org/10.2308/accr-50420

Krishnan, G., \& Visvanathan, G. (2008). Does the SOX definition of an accounting expert matter? The association between audit committee directors' accounting expertise and accounting conservatism. Contemporary Accounting Research, 25(3), 827-858. https://doi.org/10.1506/car.25.3.7

Lee, H. S., Li, X. \& Sami, H. (2015). Conditional conservatism and audit fees. Accounting horizons, 29(1), 83-113. https://doi.org/10.2308/acch-50928

Roychowdhury, S. (2006). Earnings management through real activities manipulation. Journal of Accounting and Economics, 42(3), 335-370. https://doi.org/10.1016/j.jacceco.2006.01.002

Wang, X., Yu, J., \& Fan, G. (2013). Business Environment Index for China's Provinces. China CITIC Press.

Watts, R. L. (2003). Conservatism in accounting. Part I: Explanations and implications. Accounting Horizons, 17(3), 207-221. https://doi.org/10.2139/ssrn.371820

Zhang, J. X., \& Wang, Y. (2013). Accounting conservatism and corporate financial constrains: conditional vs. unconditional conservatism. Accounting Research, 44-50 (In Chinese).

\section{Note}

Note 1. In the previous researches, CONSER_NOA is measured by non-operating accruals divided by the average total assets. The average total assets can be spread over 3 years or 5 years or 10 years (Givoly and Hayn, 2000; Krishnan and Visvanathan, 2008; Pae et al., 2007; Louis et al., 2009). 